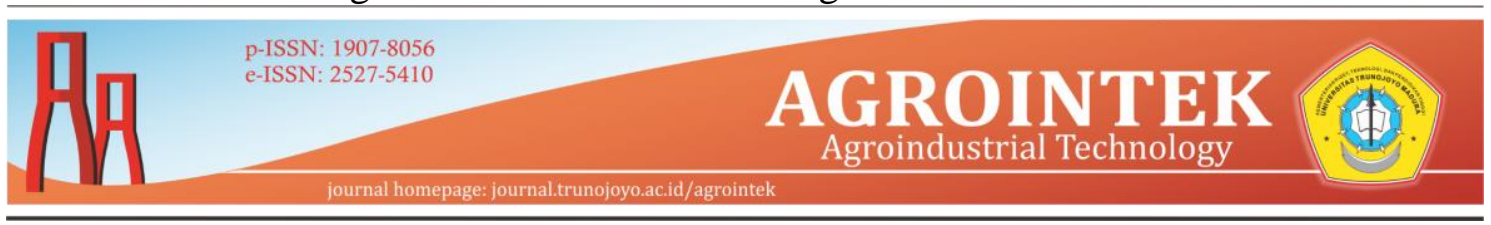

\title{
PEMBUATAN SABUN CAIR BERBAHAN BAKU MINYAK KELAPA DENGAN BERBAGAI VARIASI KONSENTRASI EKSTRAK TEH PUTIH
}

\author{
Asri Widyasanti ${ }^{1 \dagger}$, Adryani Tresna Winaya ${ }^{1}$, S. Rosalinda ${ }^{1}$ \\ ${ }^{1}$ Departemen Teknik Pertanian dan Biosistem, Universitas Padjadjaran, Bandung, Indonesia
}

Article history

Diterima: 30 Maret 2019

Diperbaiki:19 Juni 2919

Disetujui:26 Juni 2019

Keyword

extract white tea,

coconut oil,

liquid soap

\begin{abstract}
Coconut oil is one of the soap base materials that can be used, because it has a high content of lauric acid. The addition of white tea extract served as an active substance to add properties functions. The purpose of this study was to determine the effect of adding white tea extract to the characteristics of liquid soap. This study was used an experimental laboratory method with regression-correlation analysis and descriptive analysis. The treatments in this study were the addition of white tea extract concentrations ( $1 \% v / v)$ of $A=0 \%(w / v), B$ $=0.5 \%(w / v), C=1.0 \%(w / v), D=1.5 \%(w / v)$, and $E=2.0 \%(w / v)$, out of 300 grams soap basis. Parameters observed included specific gravity, $\mathrm{pH}$, total plate count, organoleptic test, and antibacterial test of liquid soap. The analysis results showed that every formulas met the requirement based on SNI 06-40851996 of liquid soap. The liquid soap formula with D treatment was the best product according to organoleptics test with a percent of $40 \%$. The antibacterial test was showed liquid soap formula with $E$ treatment has a strong bacterial inhibitory activity of $12.93 \mathrm{~mm} \pm 0.33$ with a specific gravity value of 1.025 $\mathrm{g} / \mathrm{g} \pm 0.002, \mathrm{pH} 9.23 \pm 0.059$, and a total plate value of 5.5 $\times 10^{4}$ colonies $/ g \pm 0$.
\end{abstract}

(C) hak cipta dilindungi undang-undang

\footnotetext{
$\dagger$ Penulis korespondensi

Email: asri.widyasanti@unpad.ac.id

DOI: http://dx.doi.org/10.21107/agrointek.v13i2.5102
} 


\section{PENDAHULUAN}

Sabun merupakan salah satu produk non-pangan yang cukup penting, dan sering digunakan manusia untuk membersihkan diri. Sabun tidak hanya dapat digunakan untuk membersihkan diri, namun dapat berguna sebagai obat penyakit kulit yang disebakan oleh jamur atau bakteri. Berdasarkan bentuk fisiknya sabun yang sering digunakan adalah sabun cair dan sabun padat. Namun saat ini sabun cair lebih banyak diminati oleh masyarakat. Sabun cair memiliki keunggulan yaitu mudah digunakan, disimpan, dan lebih higienis bagi konsumen.

Proses pembuatan sabun terjadi antara asam lemak yang ada pada minyak bereaksi dengan larutan alkali garam atau basa kuat yang kemudian ditambahkan dengan pewangi maupun antiseptik. Reaksi tersebut dikenal dengan reaksi safonifikasi, safonifikasi merupakan proses penyabunan yang mereaksikan suatu lemak atau gliserida dengan basa.

Minyak kelapa merupakan salah satu bahan baku sabun yang dapat digunakan, berdasarkan kandungan asam lemaknya minyak kelapa memiliki kandungan asam laurat yang tinggi. Asam laurat $\left(\mathrm{C}_{12} \mathrm{H}_{24} \mathrm{O}_{2}\right)$ tergolong kedalam jenis asam lemak rantai menengah (medium chains tryglicherides). Menurut Gani et al., (2005) asam laurat mampu memberikan sifat berbusa yang sangat baik, dan asam laurat yang berkhasiat sebagai antimikroba alami, sehingga minyak kelapa dapat digunakan sebagai bahan baku sabun.

Penambahan zat aktif dapat dicampurkan kedalam formulasi sabun, penambahan tersebut bertujuan untuk menambah fungsi khusus sabun lainnya. Bahan lainnya yang digunakan dalam pembuatan sabun cair pada penelitian ini adalah ekstrak teh putih. Teh putih memiliki banyak manfaat diantaranya adalah sebagai antibakteri, antikanker, antioksidan, antiobesitas, dan anti-aging (Preedy,2013).

Berdasarkan pemaparan tersebut penggunaan asam laurat pada minyak kelapa dengan tambahan ekstrak teh putih pada pembuatan sabun cair, dapat menghasilkan sabun cair dengan efektifitas yang baik. Asam laurat pada minyak akan memberikan karakteristik sabun yang lembut di kulit dan efek pembusaan yang baik, sedangkan katekin pada ekstrak teh putih memberikan efek antibakteri pada sabun. Pada penelitian ini memerlukan formulasi yang tepat untuk menghasilkan sabun cair dengan campuran minyak kelapa dan ekstrak teh putih.

Tujuan penelitian ini adalah mengetahui proses pembuatan sabun cair berbasis minyak kelapa. Mendapatkan sediaan yang sesuai untuk pembuatan sabun cair berbasis minyak kelapa dengan tambahan ektrak teh putih. Mengetahui mutu sabun cair yang dihasilkan terhadap standar mutu sabun cair SNI 06-40851996

\section{METODE}

Alat-alat yang digunakan adalah timbangan analitik, beaker glass $250 \mathrm{ml}$, beaker glass $500 \mathrm{ml}$, batang pengaduk, slow cooker, pipet volum $10 \mathrm{ml}, \mathrm{pH}$ meter, gelas ukur $100 \mathrm{ml}$, erlenmeyer 250 $\mathrm{ml}$, Ultrasound processor, Rotary vacuum evaporator, piknometer, pipet ukur $10 \mathrm{ml}$, tabung reaksi, cawan petri, lemari pengeram $36 \pm 1{ }^{\circ} \mathrm{C}$, alat penghitung koloni (colony counter), oven, cawan, erlenmeyer asah, thermometer digital, masker dan sarung tangan. 
Tabel 1 Formulasi pembuatan sabun cair dengan berbagai konsentrasi ekstrak teh putih

\begin{tabular}{|c|c|c|c|c|c|}
\hline \multirow{2}{*}{ Bahan } & \multicolumn{5}{|c|}{ Perlakuan } \\
\hline & A & B & C & D & $\mathbf{E}$ \\
\hline Minyak Kelapa & 75 & 75 & 75 & 75 & 75 \\
\hline Kalium Hidroksida $(\mathrm{KOH}) 30 \%$ & 52,5 & 52,5 & 52,5 & 52,5 & 52,5 \\
\hline Gliserin & 10,25 & 10,25 & 10,25 & 10,25 & 10,25 \\
\hline Propilena Glikol & 22,5 & 22,5 & 22,5 & 22,5 & 22,5 \\
\hline Aquadest & 134,29 & 132,79 & 131,29 & 129,79 & 128,29 \\
\hline Coco-DEA & 5,46 & 5,46 & 5,46 & 5,46 & 5,46 \\
\hline Ekstrak Teh Putih & 0 & 1,5 & 3 & 4,5 & 6 \\
\hline
\end{tabular}

Bahan baku utama yang digunakan dalam penelitian ini adalah minyak kelapa Delfico dan ekstrak teh putih yang didapatkan dari Pusat Penelitian Teh dan Kina (PPTK) Gambung, Jawa. Bahan kimia yang digunakan yaitu Kalium hydroxide $(\mathrm{KOH}) 30 \%$, gliserin, aquadest, propilena glikol, coco-DEA, etanol $96 \%$, phenolphtalein (PP), dietil eter, media plate count agar (PCA), buffered peptone water (BPW), dan alkohol $70 \%$.

Metode penelitian yang digunakan adalah metode eksperimental laboratorium dengan menggunakan analisis korelasiregresi dan analisis deskriptif untuk menggetahui pengaruh perlakuan variasi konsentrasi ekstrak teh putih terhadap kualitas mutu sabun cair yang dihasilkan.Penelitian ini dilakukan dengan 5 taraf perlakuan, yaitu penambahan konsentrasi ekstrak teh putih $(1,0 \% \mathrm{v} / \mathrm{v})$ sebesar $\mathrm{A}=0 \%(\mathrm{~b} / \mathrm{v}), \mathrm{B}=0,5 \%(\mathrm{~b} / \mathrm{v}), \mathrm{C}=$ $1,0 \%(\mathrm{~b} / \mathrm{v}), \mathrm{D}=1,5 \%(\mathrm{~b} / \mathrm{v})$, dan $\mathrm{E}=2,0 \%$ (b/v). Pada setiap perlakuaan dilakukan 3 kali ulangan untuk memperkecil kesalahan dalam penelitian.Formulasi pembuatan sabun mandi cair dengan berbagai konsentrasi ekstrak teh putih disajikan pada Tabel 1.

\section{Persiapan Bahan Baku Pembuatan Sabun}

Tahapan persiapan bahan baku terdiri dari mempersiapkan bahan-bahan kimia untuk pembuatan sabun cair. Persiapan bahan antara lain $\mathrm{KOH}$ padat menjadi larutan $\mathrm{KOH}$ dengan konsentrasi $30 \%$ b/v. Selain itu bahan penunjang untuk pengujian mutu sabun mandi cair yaitu Bahan - bahan kimia yang digunakan yaitu etanol 96\%, phenolphtalein (PP), aseton, dietil eter, media plate count agar (PCA), buffered peptone water (BPW), dan alkohol $70 \%$.

\section{Pembuatan ekstrak teh putih dengan menggunakan metode UAE.}

Pembuatan ekstrak teh putih dengan pelarut etanol $96 \%$ dengan perbandingan $1: 100 \quad(\mathrm{~b} / \mathrm{v})$ menggunakan Ultrasound Processor selama 30 menit dengan amplitudo $100 \%$, frekuensi $20 \mathrm{kHz}$, dan $500 \mathrm{~W}$. Penyaringan dilakukan dengan menggunakan kertas saring whatman no 42. Hasil ekstraksi yang telah dipisahkan dari padatan diuapkan kandungan pelarutnya menggunakan rotary vacuum evaporator pada suhu $40^{\circ} \mathrm{C}$, dan putaran $55 \mathrm{rpm}$.

\section{Pembuatan Sabun Cair dengan Penambahan Ekstrak Teh Putih}

Proses pembuatan sabun menggunakan metode hot process. Minyak kelapa dipanaskan dengan slowcooker. Selanjutnya memasukkan larutan $\mathrm{KOH} 30 \%$ dan diaduk hingga homogen. Selanjutnya melakukan clarity test dan mengamati warna dari hasil pasta sabun. Kemudian memasukkan aquades, gliserin dan PG. Selanjutnya menurunkan suhu dan memasukkan Coco DEA dan ekstrak teh putih. Tahap terakhir pengkondisian penyimpanan sabun mandi cair selama 24 jam. Proses pembuatan Sabun Cair dengan penambahan ekstrak teh putih dapat dilihat pada Gambar 1 . 


\section{Pengujian Mutu Sabun Cair}

Prosedur untuk uji mutu sabun cair yang dihasilkan sesuai dengan SNI 064085-1996 mengenai syarat mutu sabun mandi cair, yaitu meliputi bobot jenis, nilai $\mathrm{pH}$, dan bobot jenis. Selain uji antibakteri dan uji organoleptik terhadap warna, aroma, banyak busa, kesan saat pemakaian dan kesan setelah pemakaian.

\section{HASIL DAN PEMBAHASAN}

\section{A. Rendemen Sabun}

Pembuatan sabun cair minyak kelapa dilakukan dengan menggunakan metode hot process. Proses pembuatan sabun dimulai dengan pembuatan pasta sabun selama 3 jam yang dilanjutkan dengan proses dilusi selama 2,5 jam. Total bahan yang digunakan pada pembuatan sabun yaitu 300 gram, akan tetapi setelah melalui proses tersebut produk sabun yang dihasilkan menjadi berkurang. Massa akhir sabun yang dihasilkan berkisar \pm 146,0325g. Tabel 2 merupakan hasil pengukuran rendemen pembuatan sabun kelapa dengan ekstrak teh putih, sedangkan Gambar 2 merupakan penampakan visual dari sabun yang dihasilkan.

Nilai rendemen yang dihasilkan dari setiap perlakuan sabun tidak sama, karena selama proses pembuatan sabun dipengaruhi oleh berbagai faktor. Faktor yang mempengaruhi banyaknya rendemen sabun diantaranya adalah penguapan zat yang terjadi selama proses pembuatan sabun. Menurut (Widyasanti et.al., 2019) penguapan disebabkan adanya zat menguap berupa akuades yang ditambahkan ke dalam formulasi sabun cair. Adanya lapisan minyak yang terdapat di bagian atas sabun sebanyak $\pm 28,541 \mathrm{~g}$ setelah penyimpanan 1 minggu juga mempengaruhi rendemen, lapisan minyak ini harus dipisahkan sehingga rendemen akhir sabun menjadi berkurang. Hal yang sama juga terjadi dalam rendemen pembuatan sabun cair berbasis minyak kelapa dengan metode heat infusions, dimana adanya sejumlah lapisan minyak sekitar $17,05 \%$ dari total berat sabun cair yang dihasilkan harus dipisahkan dari sabun cair (Uswah et.al, 2019). Sisa - sisa sabun cair yang menempel pada slowcooker dan sulit untuk dipindahkan ke dalam botol kemasan sabun juga menyebabkan adanya sejumlah massa yang hilang dan mempengaruhi rendemen.

Tabel 2 Pengukuran rendemen sabun cair

\begin{tabular}{ccc}
\hline Perlakuan & $\begin{array}{c}\text { Rendemen } \\
(\%)\end{array}$ & SD \\
\hline A & 45,94 & 4,036 \\
B & 46,55 & 2,235 \\
C & 48,04 & 3,244 \\
D & 47,99 & 3,474 \\
E & 54,86 & 2,356 \\
\hline
\end{tabular}




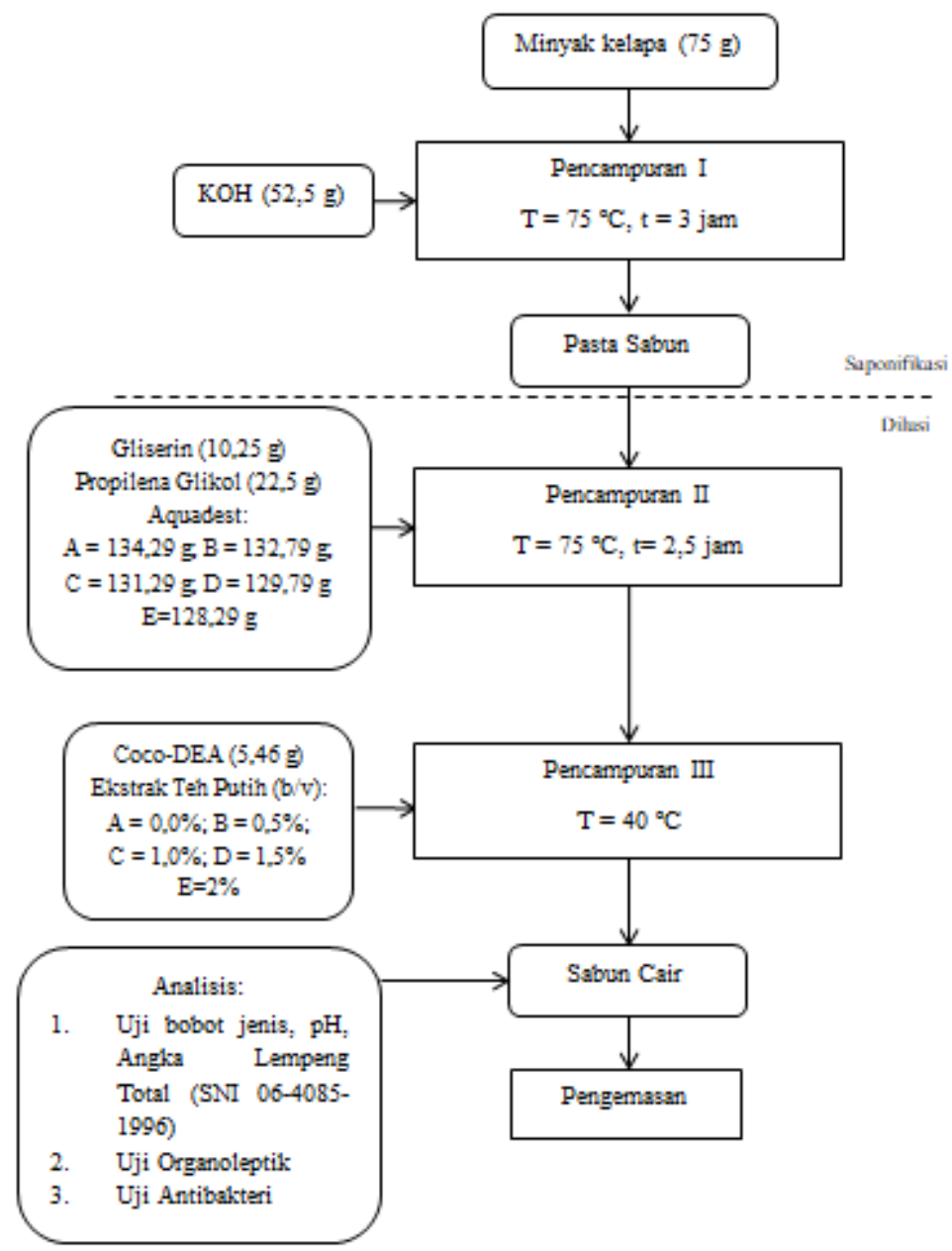

Gambar 1 Diagram Proses Pembuatan Sabun Mandi Cair

\section{Analisis Sabun Mandi Cair (SNI 06- 4085-1996)}

Bobot Jenis

Bobot jenis merupakan perbandingan bobot zat di udara pada suhu $25^{\circ} \mathrm{C}$ terhadap bobot air dengan volume dan suhu yang sama (Voight, 1994). Bobot jenis dalam sabun cair tersebut dapat dilihat pada Gambar 3.

Hasil pengukuran menunjukan bobot jenis pada sabun cair terendah dimiliki sabun cair pada perlakuan A (konsentrasi minyak kelapa $100 \%$ ) yaitu $1.0220 \mathrm{~g} / \mathrm{g} \pm$ 0.0081 , sedangkan nilai bobot jenis tertinggi di dapatkan pada sabun cair perlakuan E yaitu 1,0253 g/g $\pm 0,00201$.

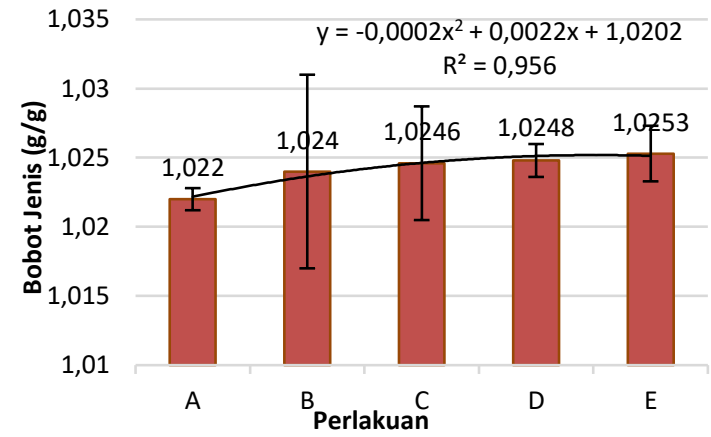

Gambar 2 Pengukuran bobot jenis dalam sabun mandi cair.

Peningkatan bobot jenis diduga diakibatkan oleh pengaruh penambahan ekstrak teh putih pada sediaan sabun. Bobot jenis ekstrak teh putih lebih tinggi dibandingkan bobot jenis minyak kelapa. Karakteristik bobot jenis ekstrak teh putih 
hasil ekstrasi berbantu ultrasonik (UAE) sebesar $1,0306 \mathrm{~g} / \mathrm{g}$ (Widyasanti et al, 2018). Perbedaan nilai bobot jenis dapat disebabkan oleh jenis dan konsentrasi bahan baku dalam larutan. Setiap bahan baku yang ditambahkan dalam formulasi sabun sangat menentukan bobot jenis produk sabun yang dihasilkan. Semakin tinggi bobot bahan baku yang ditambahkan, maka bobot jenis sabun yang dihasilkan akan semakin tinggi (Nurhadi, 2012).

Melihat nilai koefisien determinasi atau R2 (R-square) pada grafik yang disajikan pada grafik, dapat dilihat bahwa nilai koefisien determinasi atau nilai R2 yang dihasilkan cukup tinggi yaitu 0,956. Nilai koefisien determinasi menunjukkan nilai keeratan atau hubungan antara bobot jenis dan penambahan ekstrak teh putih. Nilai 0,956 dapat diartikan dengan 95,6\% perubahan bobot jenis dapat dipengaruhi oleh penambahan ekstrak teh putih sedangkan 4,4\% dipengaruhi oleh faktor lainnya. Berdasarkan nilai R-square, didapat nilai koefisien korelasi (r) yaitu dengan mengakarkan nilai R2, sehingga dihasilkan nilai $r=0,977$. Nilai koefisien korelasi 0,977 termasuk pada kategori sangat kuat, korelasi antara bobot jenis terhadap penambahan ekstrak teh putih sangat kuat, atau peningkatan bobot jenis yang dipengaruhi oleh penambahan ekstrak teh putih sangat kuat.

Nilai bobot jenis menunjukkan sabun cair yang dihasilkan sudah memenuhi kriteria SNI 06-4085-1996 yaitu bobot jenis berkisar dari 1,01 - 1,10. Pada parameter bobot jenis ini tidak ada perbedaan yang cukup tinggi pada tiap konsentrasi ekstrak teh putih yang ditambahkan untuk bahan baku pembuatan sabun cair, akan tetapi memiliki korelasi positif dimana nilai bobot jenis semakin besar dengan semakin banyaknya ekstrak teh putih yang ditambahkan.
Nilai pH

Pada produk kosmetika, nilai $\mathrm{pH}$ sangat perlu diperhatikan karena nilai $\mathrm{pH}$ dapat mempengaruhi daya absorpsi kulit. Nilai $\mathrm{pH}$ sabun cair yang diizinkan oleh SNI,1996 umumnya berkisar antara 8 hingga 11. Nilai $\mathrm{pH}$ sabun cair yang sangat tinggi atau sangat rendah dapat mempengaruhi daya absorbansi kulit sehingga menyebabkan iritasi pada kulit seperti luka, gatal atau mengelupas (Wasitaatmaja, 1997). Pengukuran nilai $\mathrm{pH}$ pada sabun cair dapat dilihat pada Gambar 4.

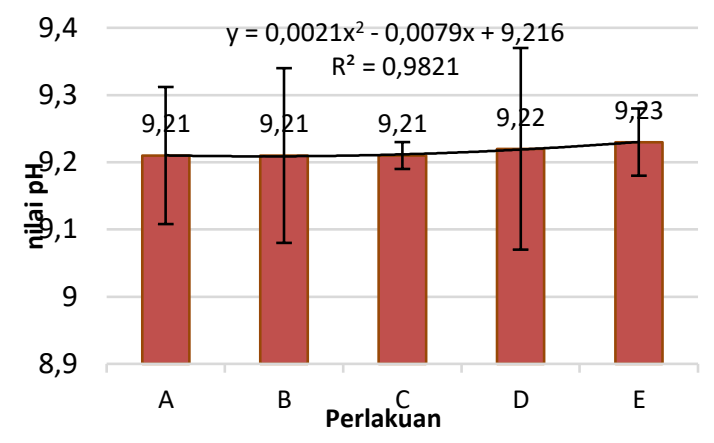

Gambar 3 Pengukuran nilai $\mathrm{pH}$ dalam sabun mandi cair.

Hasil pengukuran $\mathrm{pH}$ yang diperoleh menunjukkan sabun $\mathrm{E}$ memiliki nilai $\mathrm{pH}$ yang paling besar yaitu 9,23 $\pm 0,059$ sedangkan untuk sabun $\mathrm{A}, \mathrm{B}$, dan $\mathrm{C}$

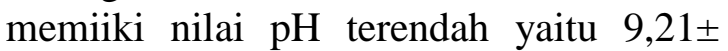
0,102 . Penambahan ekstrak teh putih tidak menunjukan peningkatan nilai $\mathrm{pH}$ sabun secara signifikan, $\mathrm{pH}$ sabun $\mathrm{A}, \mathrm{B}, \mathrm{C}$ sabun cair cenderung stabil, akan tetapi pada perlakuan sabun $\mathrm{D}$ dan $\mathrm{E}$ mengalami sedikit kenaikan. Sabun cair memiliki $\mathrm{pH}$ basa, hal ini dikarenakan bahan dasar penyusun sabun cair adalah $\mathrm{KOH}$ yang bersifat basa kuat. Peningkatan nilai $\mathrm{pH}$ pada sabun $\mathrm{D}$ dan $\mathrm{E}$ diduga disebabkan oleh penambahan ekstrak teh putih. Berdasarkan pengukuran $\mathrm{pH}$ ekstrak teh putih sebesar 5 (bersifat asam), akan tetapi semakin besar penambahan konsentrasi ekstrak teh putih dimungkinkan terdapat penambahan 
senyawa aktif alkanoid dalam teh yang merupakan senyawa organik yang bersifat alkali (Lenny, 2006), sehingga penambahan ekstrak teh putih pada sabun akan menyebabkan peningkatan nilai $\mathrm{pH}$ pada sabun.

Pada grafik yang disajikan pada Gambar 4, diketahui bahwa nilai koefisien determinasi atau R2 dari persamaan polymonial yang dihasilkan yaitu 0,9821 . Nilai R2 sebesar 0,9821 menunjukkan 98,21\% perubahan nilai $\mathrm{pH}$ dipengaruhi oleh penambahan ekstrak teh putih, sedangkan nilai $r$ adalah hasil pengakaran nilai R2 yaitu 0,991. Nilai $r$ atau koefisien korelasi 0,991 termasuk pada kategori sangat kuat, korelasi antara $\mathrm{pH}$ terhadap penambahan ekstrak teh putih sangat kuat.

Kriteria mutu nilai $\mathrm{pH}$ yang baik untuk sabun mandi cair menurut SNI 064085-1996 berkisar antara $8-11$. Sehingga analisis nilai $\mathrm{pH}$ untuk sabun cair yang dihasilkan pada penelitian ini sudah sesuai dengan kriteria mutu SNI 064085-1996. Pada parameter $\mathrm{pH}$ ini tidak ada perbedaan yang cukup tinggi pada tiap konsentrasi ekstrak teh putih yang ditambahkan untuk bahan baku pembuatan sabun cair, akan tetapi memiliki korelasi positif dimana nilai $\mathrm{pH}$ semakin besar dengan semakin banyaknya ekstrak teh putih yang ditambahkan.

Uji angka lempeng total

Uji angka lempeng total merupakan salah satu metode yang digunakan untuk mengetahui adanya bakteri yang terkandung dalam sediaan sabun. Uji Angka Lempeng Total (ALT) dan lebih tepatnya ALT aerob mesofil atau anaerob mesofil menggunakan media padat dengan hasil akhir berupa koloni yang dapat diamati secara visual berupa angka dalam koloni (cfu) per ml/gram atau koloni/100 ml. Cara yang digunakan antara lain dengan cara tuang, cara tetes, dan cara sebar (BPOM, 2008).
Hasil pengamatan uji angka lempeng total pada sabun cair dengan berbagai konsentrasi ekstrak teh putih serta sabun pembanding dapat dilihat pada Tabel 3.

Tabel 3 Hasil uji angka lempeng total sabun

\begin{tabular}{ccc}
\hline Sampel & $\begin{array}{c}\text { Rata-rata Angka } \\
\text { Lempeng Total } \\
\text { (Koloni/g) }\end{array}$ & SD \\
\hline A & $0,275 \times 10^{5}$ & 0 \\
B & $0,85 \times 10^{5}$ & 0,354 \\
C & $1 \times 10^{5}$ & 1,414 \\
D & $0,825 \times 10^{5}$ & 0 \\
E & $0,5 \times 10^{5} 0$ & 0 \\
\hline
\end{tabular}

Sabun A memiliki nilai angka lempeng total terrendah yaitu dengan rata rata $0,275 \times 105 \pm 0,00$. Hal ini terlihat dari Tabel 3,dimana perlakuan A (kelapa $100 \%$ ) pada pengenceran 1:10000 (10-4) dan 1:100000 (10-5) hanya terdapat 1 koloni cemaran mikroba pada sabun, sedangkan sabun perlakuan $\mathrm{C}$ memiliki nilai rata-rata angka lempeng total yang terbesar yaitu $1 \times 105 \pm 1,41$. Sabun dengan perlakuan $\mathrm{C}$ (penambahan ekstrak teh putih $1,0 \%(\mathrm{~b} / \mathrm{v})$ ) pada pengenceran 1:10000 (10-5) terdapat 3 koloni cemaran mikroba pada sabun

Semakin banyak koloni bakteri pada sabun menandakan semakin besarnya cemaran atau kontaminasi bakteri yang ada pada sabun. Hasil pengujian angka lempeng total menunjukkan perbedaan diduga berasal dari banyaknya koloni yang ada, selain itu juga disebabkan beberapa faktor salah satunya adalah faktor lingkungan, dimana suhu, udara, dan kelembaban dapat mempengaruhi atau memacu tumbuhnya mikroba. Berdasarkan hasil penghitungan angka lempeng total, sabun cair dengan penambahan berbagai konsentrasi ekstrak teh putih mempunyai cemaran mikroba yang sesuai standar SNI sabun mandi cair (SNI 06-4085-1996) yaitu berkisar maksimal $1 \times 10^{5} \mathrm{koloni} / \mathrm{g}$. Diduga dalam sabun cair terdapat zat kimia yang 
memiliki sifat antimikroba baik baik aktif ekstrak teh putih. berasal dari minyak kelapa maupun bahan

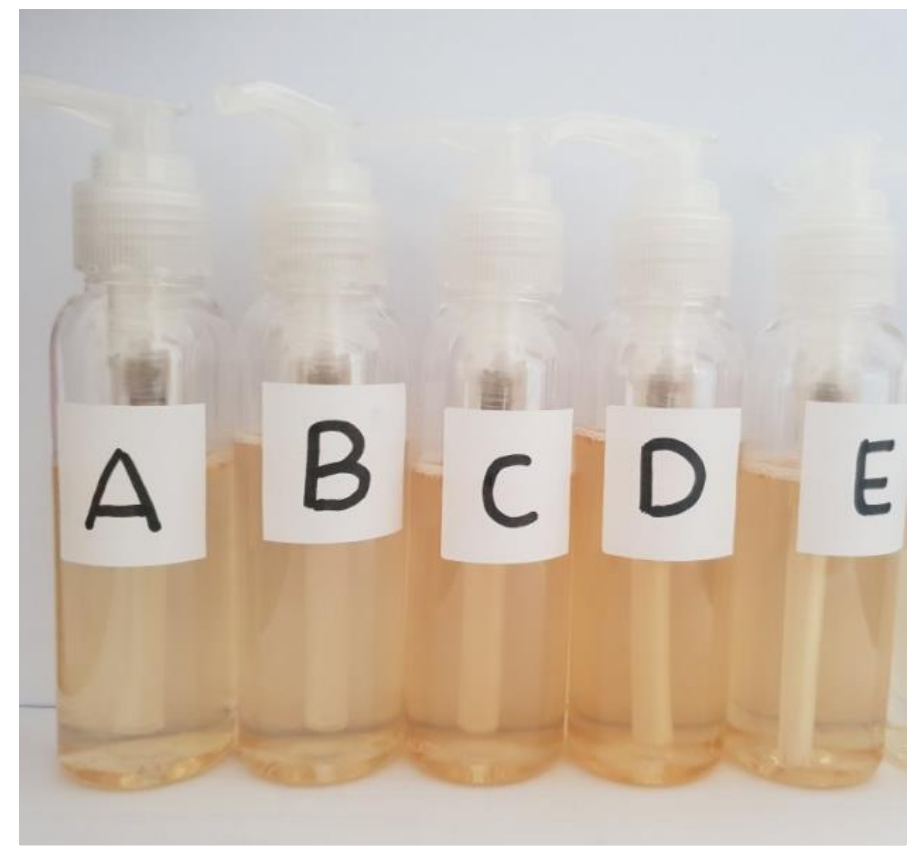

Gambar 4 Sabun kelapa dengan berbagai konsentrasi ekstrak teh putih

\section{Keterangan}

A : sabun minyak kelapa $100 \%$

B : sabun minyak kelapa dengan penambahan ekstrak teh putih $0,5 \% \mathrm{~b} / \mathrm{v}$

C : sabun minyak kelapa dengan penambahan ekstrak teh putih $1,0 \% \mathrm{~b} / \mathrm{v}$

D : sabun minyak kelapa dengan penambahan ekstrak teh putih $1,5 \% \mathrm{~b} / \mathrm{v}$

E : sabun minyak kelapa dengan penambahan ekstrak teh putih $2,0 \% \mathrm{~b} / \mathrm{v}$

Tabel 4 Hasil rekapitulasi mutu sabun cair menurut SNI 06-4085-1996

\begin{tabular}{cccccc}
\hline & \multicolumn{5}{c}{ Hasil Analisis } \\
Parameter & Perlakuan Perbedaan Konsentrasi Ekstrak Teh Putih \\
& A & B & C & D & E \\
\hline Bobot Jenis(g/g) & 1,022 & 1,024 & 1,024 & 1,0248 & 1,0253 \\
Nilai pH & 9,21 & 9,21 & 9,21 & 9,22 & 9,23 \\
Angka Lempeng Total (Koloni/g) & $0,275 \times 10^{5}$ & $0,85 \times 10^{5}$ & $1 \times 10^{5}$ & $0,825 \times 10^{5}$ & $0,55 \times 10^{5}$ \\
\hline
\end{tabular}

Tabel 5 Hasil rekapitulasi uji organoleptic

\begin{tabular}{cccccc}
\hline & \multicolumn{5}{c}{$\begin{array}{l}\text { Hasil Analisis Rata-rata Penilaian Panelis } \\
\text { Perlakuan perbedaan konsentrasi ekstrak teh putih }\end{array}$} \\
\cline { 2 - 6 } & Warna & Aroma & Banyak busa & $\begin{array}{l}\text { Kesan saat } \\
\text { pemakaian }\end{array}$ & $\begin{array}{l}\text { Kesan setelah } \\
\text { pemakaian }\end{array}$ \\
\hline A & 4 & 2 & 4 & 4 & 4 \\
B & 4 & 3 & 4 & 4 & 4 \\
C & 4 & 3 & 4 & 4 & 4 \\
D & 4 & 3 & 4 & 4 & 4 \\
E & 4 & 3 & 4 & 4 & 3 \\
\hline
\end{tabular}


Rekapitulasi Hasil dan Mutu Sabun Mandi Cair

Hasil analisis dari uji mutu sabun cair minyak kelapa setiap perlakuan dengan berbagai konsentrasi ekstrak teh putih dan dibandingkan dengan standar. Standar yang digunakan untuk uji mutu adalah Standar Nasional Indonesia untuk sabun mandi cair (SNI 06-4085-1996). Berikut merupakan hasil rekapitulasi mutu sabun cair menurut SNI 06-4085-1996 yang disajikan pada Tabel 4.

Hasil analisis uji mutu SNI 06-40851996 sabun mandi cair menunjukkan seluruh sabun cair berbasis minyak kelapa dengan tambahan berbagai konsentrasi ekstrak teh putih sudah sesuai dengan standar (SNI 06-4085-1996).

\section{Uji Antibakteri}

Antibakteri merupakan zat yang dapat mengganggu pertumbuhan atau bahkan mematikan bakteri dengan cara mengganggu metabolisme mikroba yang merugikan. Bakteri yang digunakan pada uji sabun ini adalah bakteri gram positif staphylococcus aureus yang dapat menyerang kulit. Pengukuran aktifitas antibakteri pada sabun cair tersebut dapat dilihat pada Gambar 5.

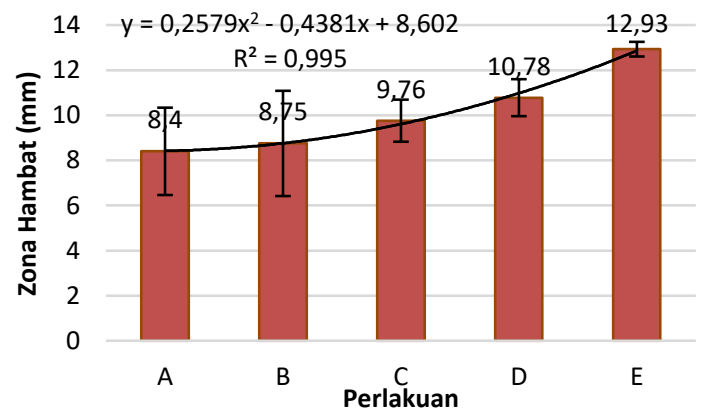

Gambar 5 Hasil uji antibakteri sabun cair

Pada Gambar 5, hasil pengukuran zona hambat bakteri staphylococus aureus menunjukkan zona hambat sabun $\mathrm{E}$ memiliki nilai tertinggi yaitu $12,93 \mathrm{~mm} \pm$ 0,33 dibandingkan dengan sabun lainnya, sedangkan nilai zona hambat sabun $\mathrm{A}$ memiliki nilai zona hambat terendah yaitu $8,4 \mathrm{~mm} \pm 1,93$. Nilai zona hambat pada sabun cair cenderung mengalami peningkatan dengan semakin banyaknya penambahan ekstrak teh putih pada sediaan sabun.

Adanya zona hambat ini menunjukkan bahwa adanya aktifitas antibakteri yang dihasilkan dari sabun. Antibakteri pada sabun berasal dari kandungan senyawa katekin yang ada pada ekstrak teh putih. Senyawa katekin pada teh putih merupakan senyawa yang mamiliki sifat antibakteri sehingga dapat menghambat pertumbuhan bakteri gram positif dan gram negatif. Hal ini diperkuat dengan penelitian Hajar (2014) yang menyatakan adanya aktifitas antibakteri dalam ekstrak teh putih terhadap gram positif maupun gram negatif. Pada penelitian tersebut zona bening atau zona hambat bakteri Staphylococos aureus yang terbentuk akibat ekstrak teh putih adalah $10,16 \mathrm{~mm}$

Melihat nilai koefisien determinasi atau R2 (R-square) pada grafik yang disajikan pada gambar 10, nilai R2 yang dihasilkan yaitu 0,995. Nilai regresi sebesar 0,995 menunjukkan 99,5 \% perubahan nilai zona hambat dipengaruhi oleh penambahan ekstrak teh putih. Berdasarkan nilai R-square, didapat nilai koefisien korelasi (r) yaitu dengan mengakarkan nilai R2,sehingga dihasilkan nilai $r=0,977$. Nilai Koefisien Korelasi 0,997 termasuk pada kategori sangat kuat, korelasi antara zona hambat bakteri terhadap penambahan ekstrak teh putih sangat kuat, atau peningkatan zona hambat bakteri yang dipengaruhi oleh penambahan ekstrak teh putih sangat kuat.

\section{Uji Organoleptik}

Uji organoleptik yang dilakukan merupakan uji kesukaan atau uji 
Organoleptik. Pada uji Organoleptik panelis diminta untuk memberikan tanggapan tentang tingkat kesukaan atau ketidaksukaannya terhadap produk sabun cair yang dihasilkan. Panelis diminta untuk menilai warna, aroma, banyak busa, kesan saat pemakaian dan kesan setelah pemakaian. Pada uji ini melibatkan 30 panelis agak terlatih dengan skala penelitian 1 sampai 5, 1= Sangat suka, $2=$ Tidak suka, $3=$ Biasa, $4=$ Suka, $5=$ Sangat suka.Berikut hasil rekapitulasi uji organoleptik sabun cair dapat dilihat pada tabel 5.

Setelah penilaian kesukaan panelis terhadap warna, aroma, banyak busa, kesan saat pemakaian dan kesan setelah pemakaian selanjutnya penilaian secara umum sabun cair yang dihasilkan. Produk

Tabel 6 Penilaian kesukaan panelis secara umum pada sabun cair sabun cair yang dihasilkan diurutkan dari rangking 1-5 yaitu sabun yang paling disukai sampai sabun yang tidak disukai. Respon kesukaan panelis secara umum pada sabun cair terhadap perbedaan konsentrasi ekstrak teh putih yang ditambahakan dapat dilihat pada Tabel 6

Pada Tabel 6 terlihat bahwa untuk sabun terbaik berdasarkan presentase kesukaan secara umum sebanyak $40 \%$ panelis menyatakan perlakuan D menempati rangking 1 , perlakuan $\mathrm{E}$ sebanyak $23 \%$ ada pada peringkat ke 2 ditempati, kemudian perlakuan $\mathrm{C}$ sebanyak $30 \%$ pada peringkat ke 3 , peringkat ke 4 pada perlakuan B sebanyak $37 \%$ dan peringkat ke 5 pada perlakuan A sebanyak $30 \%$.

\begin{tabular}{lccccc}
\hline \multirow{2}{*}{ Keterangan } & \multicolumn{7}{c}{ Perlakuan } \\
\cline { 2 - 6 } & A & B & C & D & E \\
\hline Rangking 1 & $20 \%$ & $13 \%$ & $17 \%$ & $40 \%$ & $7 \%$ \\
Rangking 2 & $23 \%$ & $20 \%$ & $13 \%$ & $23 \%$ & $23 \%$ \\
Rangking 3 & $17 \%$ & $7 \%$ & $30 \%$ & $23 \%$ & $27 \%$ \\
Rangking 4 & $10 \%$ & $37 \%$ & $23 \%$ & $0 \%$ & $27 \%$ \\
Rangking 5 & $30 \%$ & $23 \%$ & $17 \%$ & $13 \%$ & $17 \%$ \\
\hline
\end{tabular}

\section{KESIMPULAN}

1) Hasil analisis uji organoleptik sabun cair menunjukkan sabun cair pada perlakuan D (penambahan ekstrak teh putih $1,5 \% \mathrm{~b} / \mathrm{v}$ ) merupakan sabun cair terbaik berdasarkan hasil uji organoleptik oleh panelis dengan persentase $40 \%$.

2) Hasil analisis uji antibakteri pada sabun cair menunjukkan sabun cair pada perlakuan $\mathrm{E}$ (penambahan ekstrak teh putih $2,0 \% \mathrm{~b} / \mathrm{v}$ ) memiliki aktifitas daya hambat bakteri yang kuat yaitu $12,93 \mathrm{~mm} \pm 0,33$. Semakin banyak penambahan ekstrak, maka aktivitas antibakteri akan menjadi semakin kuat. Kandungan katekin pada ekstrak teh putih memberikan manfaat antibakteri pada sabun cair yang dihasilkan.

3) Hasil analisis uji bobot jenis, $\mathrm{pH}$, dan Angka Lempeng Total (ALT) sabun mandi cair menunjukkan seluruh sabun cair berbasis minyak kelapa dengan tambahan berbagai konsentrasi ekstrak teh putih sudah sesuai dengan standar (SNI 06-40851996) sabun mandi cair.

Saran pada penelitian ini adalah diperlukan penelitian lebih lanjut mengenai variasi konsentrasi $\mathrm{KOH}$ yang ditambahkan pada sediaan sabun minyak 
kelapa karena masih terdapat $\pm 28,541 \mathrm{~g}$ minyak yang tidak tersabunkan secara sempurna.Diperlukan tambahan fragrance dalam sedian sabun, sehingga sabun lebih diminati oleh konsumen. Tidak perlu penambahan ekstrak teh putih yang terlalu kental karena dengan penambahan ekstrak teh putih $1,0 \% \mathrm{v} / \mathrm{v}$ sudah memiliki nilai daya hambat yang baik.

\section{DAFTAR PUSTAKA}

Badan Pengawas Obat dan Makanan Republik Indonesia. 2008. Pengujian Mikrobiologi Pangan. Jurnal No. 2, Vol. 9. ISSN 18299334.

Gani, Z., et al. 2005. Bebas Segala Penyakit dengan VCO. Jakarta:Puspa Swara.

Lenny S, 2006. Senyawa Flavonoida, Fenilpropanoida dan Alkaloida. [Skripsi]. Universitas Sumatera Utara, Fakultas Matematika dan Pengetahuan Alam. Medan

Nurhadi, S.C., 2012, Pembuatan Sabun Mandi Gel Alami dengan Bahan Aktif Mikroalga (Chlorrela pyrenoidosa Beyerinck) dan Minyak Atsiri (Lavandula lativolia Chaix) [Skripsi], Universitas Ma Chug, Malang.

Preedy, V.R. 2013.Tea in Healty and Deases Prevention. United State of America: Academic Press. Terdapat pada: $\quad$ http://book.google.co.id (Diakses pada tanggal 3 Februari 2018 pukul 16.32 WIB)

Standar Nasional Indonesia. 1996. SNI 06-4085- 1996 Tentang Sabun Mandi Cair. Jakarta: Dewan Standardisasi Nasional.

Uswah, N. U., Widyasanti A., Rosalinda S. 2019. Perlakuan Bahan Baku Minyak Kelapa (Coconut Oil) dengan Variasi Konsentrasi Infused Oil Teh Putih (Camelia sinensis) pada Pembuatan Sabun Cair. Jurnal
Keteknikan Pertanian Tropis dan Biosistem. 7(1): 67-77

Voigt, R. 1994. Buku Pelajaran Teknologi Farmasi. Yogyakarta: Gadjah Mada University Press 